\title{
The Role of International Financial Reporting Standards (IFRS) on Encourage International Investments in the Kurdistan Region-Iraq
}

\author{
Rizgar Abdullah Sabir Jaf
}

Accounting Department, College of administration and Economics, Salahaddin University, KRG

\begin{abstract}
The present study aimed to identify the role of adopting international Financial Reporting Standards (IFRS) on Encourage International Investments in the Kurdistan Region-Iraq to the points of view of External auditors and Managers and department managers in banks and Accounting department teachers staff. The study includes two main variables the first one independent variable International Financial Reporting Standards (IFRS)(transparency, quality, disclosure and relevance) and dependent variable is Encourage International Investments. The objective of the study was to assess whether the adoption of IFRS has significant role on Encourage International Investments in the Kurdistan Region-Iraq. To answer the questions and test the hypotheses of the study, researchers relied on the descriptive analytical approach. First, the researchers clarified the theoretical aspect through previous studies, and then they analyse $d$ the results of the applied study by testing the hypothes is using the SPSS. A questionnaire was distributed after evaluation and arbitration by a number of specialists on selected sample. The sample of 90 respondents consists of general managers, department directors, head of departments, accountants, auditors and financial controllers working in the financial departments of the Kurdistan Region-Iraq. The findings of the study revealed that contrary to general expectation, the value of FDI inflow into the sector did not significantly increase after the adoption of IFRS. On the basis of the findings, we recommend amongst others that the addition to encouraging IFRS adoption, Kurdistan Region-Iraq government should create enabling environment to attract foreign direct Investment into the economy.
\end{abstract}

Keywords: International Financial Reporting Standards (IFRS), Encourage International Investments, Kurdistan Region-Iraq.

1.

During previous decades, the world has witnessed radical changes at the economic and financial level, mainly represented in the capital markets' globalization and the growth of global companies, and those results in a rise in the number of users and the diversity of their nationalities. The diversity of users needed to have financial statements containing information capable of transcending the borders of countries in a way that is understandable and useful for these users. In light of the increasing demands to standardize accounting work at the international level, to implement international accounting standards, and to achieve the optimum utilization of economic resources through making the best investment decision. This is achieved by providing

\section{Introduction}

appropriate information, especially accounting information, and the value of accounting information increases with the extent to which the preparers of the financial statements adhere to international accounting standards. The International Accounting Standards Committee (IASC) specialized in issuing these standards and then became the International Accounting Standards Board (IASB) until we reached the International Financial Reporting Standards (IFRS), which is related to the development of a set of internationally accepted standards for financial reporting. The growth in universal production and trade has resulted in a continuous improvement in foreign direct investment due to the liberalization of the global economy. Most of the world countries have 
become hosts of foreign direct investment, and among the largest countries classified as receiving and exporting foreign capital are; the Germany, USA, France, China, Brazil, Netherlands, and Sweden.

\subsection{Research Problem}

Researchers and users of financial statements focus on the implications of using a unified set of international accounting standards when preparing financial statements between different countries of the world. And because of the increasing number of countries that have adopted international accounting standards, this research aims to find out the extent of the role of adopting IFRS on encouraging and increasing foreign direct investment in the Kurdistan Region of Iraq, as a means of helping to get out of the current economic crisis in the Kurdistan Region.

\subsection{Research Importance:}

The importance of this research stems from the fact that the International Financial Reporting Standards IFRS is the organizer and determinant of the basic accounting practices in companies on a global scale, and is also the guide for the accounting work that seeks to provide foundations and procedures that enhance the effectiveness of the accounting profession in achieving relevance, confidence, and credibility in accounting information, which is one of the accounting outputs. These important reasons have pushed most countries in the developed world to move towards the application of international standards due to the important developments that the financial markets have witnessed in the last two decades, as well as the exit of companies outside the regional borders in search of sources of capital for investment, or a request from countries seeking to develop their economic reality in In light of the lack of expertise, technical and logistical capabilities, hence the role of international standards for organizing accounting transactions among those parties.

\subsection{Research Aims}

This research aims to provide a comprehensive theoretical framework for each of the international standards for financial reporting and international investments represented by foreign direct investment. This research also aims to give a true picture of the reality and prospects of international financial reporting standards in the Kurdistan Region in light of the economic reforms which has been undertaken in the current period in addition to shedding light on the development of international investments represented by foreign direct investment in the Kurdistan Region by knowing the current situation and developing a strategy to confront current and future challenges. The research also aims to achieve the following goals:

- Defining the role of transparency in financial reports according to IFRS on encouraging international investments, including (foreign direct investment) in the Kurdistan Region.

- Determining the role of the quality of financial reports according to IFRS on encouragement of international investments, including (foreign direct investment) in the Kurdistan Region.

- Determine the role of disclosure of financial reports according to IFRS on encouragement of international investments, including (foreign direct investments) in the Kurdistan Region.

- Determine the role of relevance of financial reports according to IFRS on encouragement of international investments, including (foreign direct investments) in the Kurdistan Region.

\subsection{Research hypotheses}

Based on the research problem and to facilitate the answer to the questions asked, it has prepared the following hypotheses:

The main hypothesis of the research (there is a role of the International Financial Reporting Standards' application on encouragement of foreign direct 
investment in the Kurdistan Region). The following sub-hypotheses emerged from it:

- There is a significant correlation between transparency in financial reports by IFRS and the encouragement of international investments, including (foreign direct investments) in the Kurdistan Region.

- There is a significant effect of the transparency in financial reports by IFRS on the encouragement of international investments, including (foreign direct investments) in the Kurdistan Region-Iraq.

- There is a significant correlation between the quality of financial reports by IFRS and the encouragement of international investments, including (foreign direct investment) in the Kurdistan Region.

- There is a significant effect of the quality of financial reports by IFRS on the encouragement of international investments, including (foreign direct investment) in the Kurdistan Region-Iraq.

- There is a significant correlation between the disclosure of financial reports by IFRS and the encouragement of international investments, including (foreign direct investments) in the Kurdistan Region.

- There is a significant effect of the disclosure of financial reports by IFRS on the encouragement of international investments, including (foreign direct investments) in the Kurdistan Region-Iraq.

- There is a significant correlation between the governance of financial reports by IFRS and the encouragement of international investments, including (foreign direct investments) in the Kurdistan Region.

- There is a significant effect of the relevance of financial reports by IFRS on the encouragement of international investments, including (foreign direct investments) in the Kurdistan Region-Iraq.

\subsection{Research Methodology}

To release the aims of the study and to reach the best ways to reveal role (relationship, effect) of applying the IFRS in encouraging international investments in the Kurdistan Region, the descriptive analysis approach concerning the theoretical aspect of this study is relied upon, and the method of statistical analysis is relied upon concerning the practical aspect of the study.

\section{Theoretical framework}

\subsection{International Financial Reporting Standards}

The International Accounting Standards Committee assumed the responsibility for setting international standards from 1973 until 2001, and the International Accounting Standards Board (IASB) swapped the International Accounting Standards Committee (IASC) in 2001, and it became responsible for setting international standards and the standards issued by it were called "International Financial Reporting Standards." (IFRS). this chapter will shed light on the international financial reporting standards and financial reporting standards through the following points:

\subsubsection{IFRS implementation costs}

The adoption and implementation of International Financial Reporting Standards (IFRS) are one of the main challenges facing organizations, professional associations, users, and account compilers, as they face many problems in many economic units in different countries. The implementation of IFRS should not be viewed as an instant execution process, but it should be viewed as a restructuring process that takes time and requires great effort by accountants and auditors (Ratnam \& Tan, 2013). Nevertheless, there is a global trend towards adopting IFRS. By 2002, the European Union imposed the use of IFRS on all companies listed on their stock exchanges and put them into practice in 2005. In 2007, 
the number of countries implementing IFRS became more than 30 countries, and in 2010 more than 100 countries adopted IFRS, including Australia, China which harmonized its national standards with IFRS. The United States also allowed the adoption of IFRS in 2007 and set a target date for convergence with IFRS in 2011. By the end of 2017, more than 150 countries had committed to implementing IFRS (Pran,2010). The transition to IFRS took one of two ways, either through "complete transformation", that is, full adoption of international financial reporting standards without any modification, such as the European Union, or by "partial transformation", that is, adaptation to international financial reporting standards, taking into account the prevailing local state conditions such as China. According to Zamir (2012), the second image, "Flexible Mandatory Transformation", gives the company some freedom to act and prepare during the transition period, and the third image is "Compulsory Transfer" where the transformation process is imposed at a specific time. According to Sabir et al., (2011) The path followed by the state to complete the transfer process depends on the costs that the state can bear, as the cost of the transfer is divided into four main components, namely (training costs, program costs, consulting program costs and fees, and audit costs), the cost of the programs also includes purchase and training costs to operate the program. Attention must also be paid to education levels to adopt IFRS, as understanding, interpretation, and implementation of IFRS requires a high level of education, competence, and skills. The transformation process is costly, as the field survey conducted on the European Union states that the cost of applying IFRS in the first year is about $1.30 \%$ of sales for small enterprises, and $1.12 \%$ for large companies, which hinders some developing countries from complying with IFRS, as these countries prefer to direct their resources and funds to address other priorities such as poverty alleviation and health problems (Aida \& Carmen, 2014).

\subsubsection{IFRS Benefits}

Compliance with IFRS achieves many benefits for the economy and investors are encouraged to invest outside their countries, as investors are concerned that the financial information is appropriate, reliable, disclosed promptly, and comparable (Watts, 2003). preparing high-quality financial reports contributes to increasing investor confidence, (Holthausen, 2003). Furthermore, the quality of financial statements will be led to the recovery of the industry worldwide, as foreign capital is attracted at a low cost (Watts, R., 2003). However, if the accounting standards differ from one country to another, this will affect to an increase in the cost of preparing financial reports, and the difficulty of moving foreign capital (Jaf et al., 2012). Accounting compatibility leads to improved performance of various accounting services among countries, which means an increase in revenues resulting from practicing the profession of accounting across the world and leads to the standardization of the accounting profession in all countries (Peter, 2002). In general, achieving compatibility among accounting standards has reduced the cost of preparing financial statements, the possibility of making comparisons, developing financial markets, facilitating the movement of funds, reducing auditing costs, and also increasing their efficiency, and finally will be led to competitive advantages among companies (Jaf, et al., 2015; Metwally Fayed, 2000).

\subsubsection{Determinants of adopting international accounting standards}

There are four determinants behind the international desire to adopt international standards:

\subsubsection{The Accounting Infrastructure}

It consists of the following components:

a) The presence of strong entities with an interest in regulating standards, including securities 
authorities, banks, and others.

b) The presence of an integrated and independent organization for the development and issue of standards, which mainly includes an independent decision-making council, an expert advisory council to offer guidance and support, an accounting research and studies center to prepare standards, and a council to issue the essential applied explanations.

c) The existence of a strong professional practice represented in accountants and accounting firms.

d) Presence of adequate financial and human resources (Al-Jurf, 2010).

\subsubsection{Multinational Companies}

Foreign companies have to formulate financial statements according to several accounting principles according to the number of their subsidiaries, and then they have to reformulate consolidated financial statements (at least for internal decision-making purposes) again. Hence, the cost of producing accounting information becomes high if the standards and principles differ among countries (Sorguli \& AlKake, 2020). Moreover, the major audit offices concerned with auditing the parent company's accounts will impose high audit fees on the parent company if they are required to audit the accounts of the subsidiary companies (even if it concerns the ownership of the holding company) so that the cost of preparing and reviewing consolidated financial statements becomes a heavy burden on the companies. This may push the big companies and major audit firms on international decision-making bodies to adopt one set (or compatible groups) of accounting standards (Salah, 2008).

\subsubsection{Trading in Global Markets}

The cost of capital is one of the factors driving the economic decision as well, and to protect the investor, global stock exchanges set strict conditions for registration and trading, such as adherence to a specific set of accounting standards. If there is no international coordination among countries, then every company will be requested to prepare two sets of financial statements, the first according to the standards of the country of origin, and the second according to the standards of the host country. If we imagine the overlapping of international relations in this way, the difficulty of adhering to the rules of trading in the various countries will make without restrictions on the trading of securities of national companies abroad. For those reasons, international coordination among different countries began at two levels, the first is the bilateral and regional level, which takes the form of agreements to facilitate interdeliberations between the countries in the agreement, and the second is the global international level that takes place within the framework of global international organizations. The move on the second level has resulted in many global accounting blocs such as IFAC and financing including the World Bank and the International Monetary Fund, as well as investment concerned with investors in global stock exchanges such as the International Financial Markets Organization (IOSCO). These global organizations began to pressure different countries to adopt one set of international standards at a time when there was a committee to issue international standards, its versions were not adequately accepted at that time (Al-Majrabi 2012).

\subsubsection{Investment in Global Markets}

The problem that accompanied foreign investment operations is the difficulty of understanding the financial statements prepared under the accounting principles of the invested countries, and with the restrictions imposed on the capabilities of the foreign investor in understanding accounting matters, they have resorted to financial analysts and investment institutions and thus the cost of investment increases (Othman, et al., 2019). due to that, investor countries 
began to search for the simplest rules that reduce this cost, including adopting international accounting standards, either in an absolute or consistent manner, making the differences very small when preparing financial statements following international accounting standards, with disclosing these differences in the financial statements (Jarf, 2010).

From the above, it can be said that the existence of international accounting standards results in a kind of harmonization and uniformity in accounting practices internationally, and different countries can benefit from them in formulating and setting their accounting standards to harmonize accounting practices, which leads to the advancement and development of the accounting profession, especially in developing countries. The International Organization of Securities Commission also suggested the international financial reporting standards application for cross-border trading in securities for the sake of the public interest (Kevin \& Roger, 2014).

\subsection{Second: Foreign Direct Investment}

The concept and definition of foreign direct investment (Al-Kafri. 2010): Foreign direct investment is defined in accordance with the regulations for preparing the equilibrium of payments figures issued by the International Monetary Fund in 1993) as an international investment that reflects the acquisition of a resident entity (company, institution or bank) in any an economy based on a permanent interest in a resident institution in another economy. The resident unit is referred to as (the direct investor), and the institution is referred to as the (direct investment corporation). The permanent interest suggests the presence of a long-term connection between the direct investor and the organization, in addition to the investor having a large degree of influence in the management of the institution (Al-Kake, et al., 2019).

\subsubsection{The importance of Foreign Direct Investment}

(Al-Qashi and Al-Abadi, 2007) believes that the position of foreign direct investment appears via its impacts on the host country, as it provides many advantages that other international financial sources cannot provide, for instance:

- When linked to fixed loans, it will not be a good technique of financing.

- It required to be easiest and most effective way in order to obtain advanced technology.

- It helpful in job opportunities creation, workers' skills development, and releases new markets for exportation.

- It might contribute to support resident companies grow their production size and participate the international competitive market if circumstances are shaped to achieve this.

(Abd al-Salam, Rida, 2002, p. 36) considers that the positive effects of foreign direct investment can be divided into positive internal and external effects as follows:

- The positive effects internally. It can be summarized as follows:

- Help the economy grow, create jobs, and raise living standards.

- Speed in capital accumulation.

- Transferring scientific knowledge.

- Technology transfer to local companies.

- Indirect developmental impacts events.

- By attracting foreign investment, the host country can cover the investment gap and ensure access to the financial and technology components.

- An increase in spending on research and development.

- The positive effects on the external level can be 
summarized as follows:

- Reducing customs duties and thus encouraging import and export.

- Reducing commercial costs, making domestic goods highly competitive, and generating global revenues, thus reducing the budget deficit.

(Muhammad, 2005) believes that foreign direct investment is very important and has a fundamental role in the economy's enhancement of developing countries through:

- Providing low-income countries with a group of assets of a different and scarce nature in these countries through global companies. These assets contain capital, technology, and management skills, and it is also a frequency through which products are promoted universally.

- Contribute to creating job opportunities and reducing unemployment.

- Increase the rate of investment in developing countries.

- The spread of positive effects at the national economic level.

Capital financing by foreign companies to finance their projects contributes to increasing exports in host countries and reducing the balance of payments deficit.

\subsubsection{Forms of Foreign Direct Investment}

Foreign direct investment takes several forms, the most important of which are: (Al-Kafri. 2010).

- joint investment: These partnership types are jointly between the foreign investor and the national investor are determined according to the agreement of the partners and according to the laws regulating foreign ownership.

- Projects entirely owned by foreign companies in the host economy: This type of investment permits the foreign element to have full control in decision-making, and that is why many invested countries do not like it, lest it led to dependence and economic dominance by the foreign investor.

- Multinational companies: They are companies that own many projects in different countries of the world, as these companies are distinguished by the enormity of their activities and activities. The phenomenon of foreign direct investment through multinational companies, or the so-called transnational companies, is one of the most prominent phenomena that have occurred at the level of international economic relations during the last three or four decades.

- Determinant factors to interest foreign direct investment: In 1995, foreign direct investment in developing countries accounted for $38 \%$ of total foreign direct investment, doubling the $12 \%$ of foreign direct investment in 1990. However, the distribution of the latter among developing countries is unfair, as about $50 \%$ goes to East Asian countries and 28\% goes to Latin America. Here, the following questions are raised: What are the factors that attract foreign direct investment? Thus, one country is more attractive compared to another. In order to attract foreign investors, developing countries provide them with a variety of incentives, conveniences and privileges. However, it is wrong to believe that the diversity and diversity of incentives or conveniences and privileges given to investors will inevitably lead to an increase in the amount of foreign investment or the country's attraction to foreign investment. Saskia K.S Wilhelms (1998) analyses the determinants of attracting foreign investment in 67 developing countries for the period 1978-1995, they found that factors at the sector level are less important than the determinants at the country level. These factors are represented in the following (Saskia K.S 
Wilhelms, 1998):

a) Governmental adjustment: Government adjustment results in an increase in foreign direct investment because it decreases economic, political, legal, and administrative instability, thereby reducing the degree of risk. Government adjustment is measured by the following variables:

- Economic openness: Increasing economic openness contributes to an increase in the flow of foreign direct investment. Economic openness is that markets are free, that is, there is little state interference in the markets, that the export and import system is open.

- Integrity and transparency of law and administration: government cancellation of contracts, confiscation, bribery between governments, respect for the law, judicial status, and the quality of public employment are all factors that affect the attraction of foreign direct investment. Compared with other variables, fairness and low bribery levels have a stronger positive correlation with foreign direct investment, because these two variables have a direct impact on investment operations. Foreign investors feel bribery as soon as they arrive at the port. Just as the judicial status shows that the possibility of the government canceling the contract is very weak, the rights of investors are protected by law.

b) Market Adaptation (Cortel \& Bin Arab, 2007): Well-functioning markets increase FDI inflows. The extent of market adaptation is measured by the following variables:

- Total market adjustment: the total market adjustment is measured in the gross national product per capita, as well as the total population. The gross national product per capita shows the level of economic development and the economy' s productivity, while the total number of the population displays after the market, i.e., the size of the market.

- Urban Population to Total Population Ratio: There is a strong positive relationship between FDI and urbanization.

- Rural population density: The density of rural population is correlated with foreign direct investment positively, meaning that, this variable encourages foreign direct investment because the large population density in rural zones means the development of infrastructure for these zones and their incorporation into urban zones.

- Adaptation of the market for goods and services.

- Capital market adjustment.

- Commercial use of energy: Commercial energy use is closely and strongly related to foreign direct investment. Foreign investors are their primary preoccupation with access to energy and communications. The energy factor can be viewed by a foreign investor as compensation for weak infrastructure structures.

c) Adaptation concerning education (Saskia Wilhelms, 1998): a high percentage of education means the presence of an educated workforce, and this increases the inflows of direct foreign investment.

d) Socio-cultural adaptation: (Jaf \& Hamid, 
2021) This refers to the local behaviors and trends of the host country that are capable of influencing the entry of domestic foreign investment.

It can be seen that most of the variables that have an impact on attracting foreign direct investment are government and market variables. As the government's adjustment is reflected in economic honesty, fairness, and lawful and managerial transparency. Economic openness means reducing customs duties to the lowest possible level, controlling exchange rates, and eliminating bribery. On the other hand, it means adapting the market, embodying a high volume of exchanges, weak taxes, urbanization rates, a high volume of loans, and a large amount of energy availability.

\subsubsection{Empirical Side}

To test research hypotheses and reach successful solutions those contribute to addressing its problem and are realistic in that the influence of applying the International Financial Reporting Standards (IFRS) to encourage international investments in the Kurdistan Region, the following categories were chosen: Checker. Investors. The vocabulary of the research sample was chosen from among institutional investors and representatives of the 35 companies and banks. This is to ensure the selection of a competent and knowledgeable sample of the subject of the study and to obtain more accurate results. People who have research interests in investments and the university professor, who number 20. To prove the hypothesis (there is a role of the application of IFRS on the encouragement of foreign direct investment in the Kurdistan Region). In the analysis of the research sample, reliance was made through the distribution of (105) questionnaires. After completing the process of collecting and examining the forms, it was found that the number of forms whose answers were completed and were ready for analysis reached (90) forms. The process of preparing, distributing, receiving, unloading, and processing the questionnaire took two months, specifically in 2019, as it represents time limits for the research. As for the spatial limits of the research, it included the university professor and the principals, the banks operating in the region. We could not mention their names, the external auditors, and the investors. The spatial limits of the research are considered.

The study population, which numbered 90 questionnaires, consisted of the following categories:

- The 35 external auditors are accredited by the Association of Certified Public Accountants in the Kurdistan Region.

- Investors. The vocabulary of the research sample was chosen from among institutional investors and representatives of the 35 companies and banks. This is to ensure the selection of a competent and knowledgeable sample of the subject of the study and to obtain more accurate results.

- People with research interests in investments and the university professor, who number 20.

a) Data collection: The survey list was distributed to the study category, where 105 questionnaires were distributed, and 94 questionnaires were obtained, of which 4 were excluded, so that the number of valid forms was 90, with a ratio of $\% 87.55$, which is acceptable rates for completing the research, and relying on the results obtained from them.

b) The statistical methods used: The statistical program (SPSS) was used in conducting the statistical analysis of the study data, where the correlation coefficients were used to measure the degree of correlation between the study variables, in order to measure the strength and direction of 
the linear relationship between the variables, and the relationship is statistically strong if the significance level of the statistical test is Small less than (0.05) As for the sign, it indicates the direction of the relationship between the variables. If it is positive, then the relationship is positive, and if it is negative, the relationship is inverse. The alpha coefficient was also used to evaluate the reliability of a set of statements that measure each variable, to examine the extent of reliance on the results of The field study, and the absence of bias or distortion in the results when analyzing, as \%50 represents the acceptable minimum for the alpha coefficient, and the highreliability rates reflect the high degree of internal consistency between the contents of each variable, and the possibility of reliance on these variables in practice.

\section{Analyze Results and Test Hypotheses}

H1: There is a significant correlation between transparency in financial reports by IFRS and the encouragement of international investments, including encouragement of international investments (Foreign Direct Investment) in the Kurdistan Region. Based on the results of Table No. 1 the correlation coefficient was used to measure the relationship between the independent variable, transparency in financial reports according to International Financial Reporting Standards. IFRS, as it became clear from the analysis data that the correlation coefficient reached $0.752^{* *}$ at a significant level (0.000), which indicates that there is a direct correlation between transparency in financial reports under IFRS and the promotion of international investments, including (Foreign Direct Investment) in the region. Kurdistan extracted from the financial reports, and that this relationship is of acceptable statistical significance because it is less than $\% 1$, which is the statistically acceptable level, and the strength of that relationship is strong. 
Table (1) The correlation coefficient between transparency in financial reports according by "IFRS" and encouragement of international investments (Foreign Direct Investment) in the Kurdistan region

\begin{tabular}{|c|c|c|c|}
\hline & & $\begin{array}{l}\text { Foreign } \\
\text { Direct } \\
\text { Investment }\end{array}$ & $\begin{array}{l}\text { Transparency } \\
\text { in financial } \\
\text { reporting }\end{array}$ \\
\hline \multirow{3}{*}{$\begin{array}{l}\text { encouragement } \\
\text { of international- } \\
\text { investments } \\
\text { (Foreign Direct } \\
\text { Investment) }\end{array}$} & $\begin{array}{l}\text { Pearson } \\
\text { Correlation }\end{array}$ & 1 & $0.752^{* *}$ \\
\hline & Sig. (2-tailed) & & 0.000 \\
\hline & $\begin{array}{l}\text { The number of } \\
\text { items of the } \\
\text { sample }\end{array}$ & 90 & 90 \\
\hline \multirow{3}{*}{$\begin{array}{l}\text { Transparency } \\
\text { in financial } \\
\text { reporting } \\
\text { According by } \\
\text { IFRS }\end{array}$} & $\begin{array}{l}\text { Pearson } \\
\text { Correlation }\end{array}$ & $0.752^{* *}$ & 1 \\
\hline & Sig. (2-tailed) & 0.000 & \\
\hline & $\begin{array}{l}\text { The number of } \\
\text { items of the } \\
\text { sample }\end{array}$ & 90 & 90 \\
\hline
\end{tabular}

H2- There is a significant effect of the transparency in financial reports by IFRS on the encouragement of international investments, including (foreign direct investments) in the Kurdistan Region-Iraq.

Table (2) the correlation effect of transparency in financial reports by "IFRS" on the encouragement of international investments (Foreign Direct Investment) in the Kurdistan region-Iraq

\begin{tabular}{llcccc}
\hline \hline $\begin{array}{l}\text { In depending } \\
\text { variable }\end{array}$ & $\mathrm{R}$ & $\mathrm{R} 2$ & $\begin{array}{c}\text { Adjusted } \\
\mathrm{R} 2\end{array}$ & $\mathrm{~F}$ & Sig. F \\
\hline
\end{tabular}

Transparency

in financial

$\begin{array}{llllll}\text { reporting } & 0.641 \mathrm{a} & 0.411 & 0.404 & 57.317 & 0.000\end{array}$

According by

IFRS

\begin{tabular}{lcccc}
\hline $\begin{array}{l}\text { encouragement of } \\
\text { international }\end{array}$ & $(\beta)$ & $\mathrm{T}$ & Sig. T & Sig. \\
\cline { 2 - 5 } $\begin{array}{l}\text { investments (Foreign } \\
\text { Direct Investment) }\end{array}$ & 0.641 & 7.571 & 0.000 & 0.01 \\
\hline
\end{tabular}

The results of Table (2) show that the correlation effect $\left(R=0.641^{a}\right)$ indicates presence of a positive effect of the variable of Transparency in financial reporting on the encouragement of international investments (Foreign Direct Investment) variable, and that there is an effect of the independent variable (Transparency in financial reporting) on the dependent variable encouragement of international investments (Foreign Direct Investment) which is a statistically significant effect, as the calculated value of $(\mathrm{F})$ reached (57.317) which is statistically significant at the level of ( $\mathrm{Sig}=0.000$ ) which is less than (0.05), and based on the above, the $\mathrm{H} 2$ is accepted. Financial reports for companies and financial institutions through which the appropriate decision is taken, whether by management, investors, lenders, or any other party in need of financial reports.

H3 There is a significant correlation between the quality of financial reports by IFRS and the encouragement of international investments, including encouragement of international investments (Foreign Direct Investment) in the Kurdistan Region. Based on the results of Table No. 3The correlation coefficient was used to measure the relationship between the independent variable of quality in financial reports according to the International Financial Reporting Standards. "IFRS", as it became clear from the analysis data that the correlation coefficient reached $0.602^{* *}$ at a significant level (0.000), which indicates that there is a direct correlation between the quality of financial reports according to IFRS and the encouragement of international investments, including encouragement of international investments (Foreign Direct Investment) In the Kurdistan Region, which is extracted from the financial reports, and that this relationship is of acceptable statistical significance because it is less than $\% 1$, which is the statistically acceptable level, and the strength of this relationship is strong. In the financial reports according to the International Financial Reporting Standards IFRS and the encouragement of international investments (Foreign Direct Investment), Direct prophetess in the Kurdistan Region. From the point of view of modest researchers, there is great importance for quality in the financial reports of companies and financial institutions, banks through which the appropriate decision is taken, whether by the administration, 
investors, lenders, or any other party in need of financial reports, where they spend a lot of efforts and money by the decision-makers on the financial statements or beneficiaries of the financial statements to obtain quality financial reports.

Table (3): The correlation effect of quality of the financial reports "IFRS" and the encouragement of international investments (Foreign Direct Investment) in the Kurdistan

\begin{tabular}{|c|c|c|c|}
\hline & & $\begin{array}{c}\text { Foreign Direct } \\
\text { Investment }\end{array}$ & $\begin{array}{l}\text { Quality in } \\
\text { Financial } \\
\text { Reporting }\end{array}$ \\
\hline \multirow{3}{*}{$\begin{array}{l}\text { encouragement of } \\
\text { international } \\
\text { investments } \\
\text { (Foreign Direct } \\
\text { Investment) }\end{array}$} & $\begin{array}{c}\text { Pearson } \\
\text { Correlation }\end{array}$ & 1 & $0.602^{\text {** }}$ \\
\hline & Sig. (2-tailed) & & 0.000 \\
\hline & $\begin{array}{c}\text { The number of } \\
\text { items of the } \\
\text { sample }\end{array}$ & 90 & 90 \\
\hline \multirow{3}{*}{$\begin{array}{c}\text { Quality in } \\
\text { Financial } \\
\text { Reporting } \\
\text { According by IFRS }\end{array}$} & $\begin{array}{c}\text { Pearson } \\
\text { Correlation }\end{array}$ & $0.602^{* *}$ & 1 \\
\hline & Sig. (2-tailed) & 0.000 & \\
\hline & $\begin{array}{l}\text { The number of } \\
\text { items of the } \\
\text { sample }\end{array}$ & 90 & 90 \\
\hline
\end{tabular}

H4- There is a significant effect of the quality of financial reports by IFRS on the encouragement of international investments, including encouragement of international investments (Foreign Direct Investment) in the Kurdistan Region-Iraq. The results of Table (4) show that the correlation coefficient $(\mathrm{R}=$ $0.563 \mathrm{a}$ ) indicates presence of a positive correlation between the variable of quality in financial reporting and the Foreign Direct Investment variable, and that there is an effect of the independent variable (quality in financial reporting) on the dependent variable encouragement of international investments encouragement of international investments (Foreign Direct Investment) which is a statistically significant effect, as the calculated value of $(F)$ reached (38.057) which is statistically significant at the level of (Sig $=0.000)$ which is less than (0.05), and based on the above, the fourth hypothesis is accepted. Financial reports for companies and financial institutions through which the appropriate decision is taken, whether by management, investors, lenders, or any other party in need of financial reports. In the financial reports according to the International Financial Reporting Standards IFRS and the encouragement of international investments, including (foreign investments) direct prophetess in the Kurdistan Region-Iraq.

Table (4) the correlation effect of the quality of the financial reports according by "IFRS" on the encouragement of international investments (Foreign Direct Investment) in the Kurdistan region-Iraq

\begin{tabular}{|c|c|c|c|c|c|}
\hline $\begin{array}{l}\text { In depending } \\
\text { variable }\end{array}$ & $\mathrm{R}$ & R2 & $\begin{array}{l}\text { Adjusted } \\
\text { R2 }\end{array}$ & $F$ & Sig. F \\
\hline $\begin{array}{l}\text { quality in } \\
\text { financial } \\
\text { reporting } \\
\text { According by } \\
\text { IFRS }\end{array}$ & $0.563 a$ & 0.317 & 0.309 & 38.057 & 0.000 \\
\hline \multirow{2}{*}{\multicolumn{2}{|c|}{$\begin{array}{l}\text { encouragement of } \\
\text { international investments } \\
\text { (Foreign Direct } \\
\text { Investment) }\end{array}$}} & $(\beta)$ & $\mathrm{T}$ & Sig. T & Sig. \\
\hline & & $0.563 a$ & 6.169 & 0.000 & 0.01 \\
\hline
\end{tabular}

From the point of view of modest researchers, there is great importance for quality in the financial reports of companies and financial institutions, banks through which the appropriate decision is taken, whether by the administration, investors, lenders, or any other party in need of financial reports, where they spend a lot of efforts and money by the decision-makers on the Financial statements or beneficiaries of the financial statements to obtain quality financial reports.

H5 There is a significant correlation between the disclosure of financial reports by IFRS and the encouragement of international investments, including (foreign direct investments) in the Kurdistan Region. Based on the results of Table No. 5 the correlation coefficient was used to measure the relationship between the independent variable disclosures in the financial reports under International Financial Reporting Standards. "IFRS", as it became clear from the analysis data that the correlation coefficient reached $0.891^{* *}$ at a significant level (0.000), indicating that there is a direct 
correlation between the disclosure in the financial reports under IFRS and the encouragement of international investments, including (foreign direct investment) In the Kurdistan Region, extracted from the financial reports and that this relationship is of acceptable statistical significance because it is less than $\% 1$, which is the statistically acceptable level, and the strength of this relationship is strong. Based on the results of Table No. 5, the nihilistic hypothesis is rejected and the alternative hypothesis is shifted (there is a correlation between disclosure in financial reports under IFRS and the promotion of international investments, including (foreign direct investment) in the Kurdistan Region). Great for disclosure in the financial reports of companies, financial institutions, and banks through which the appropriate decision is taken, whether by the administration, investors, lenders, or any other party in need of financial reports, as they make a lot of efforts and funds by the decision-makers on the financial statements or the beneficiaries of the financial statements in order to obtain quality financial reports.

Table (5): The correlation coefficient between the disclosure in the "IFRS" financial reports and the encouragement of international investments (foreign direct investment)in the Kurdistan Region

\begin{tabular}{|c|c|c|c|}
\hline & & $\begin{array}{l}\text { Foreign } \\
\text { Direct } \\
\text { Investment }\end{array}$ & $\begin{array}{l}\text { Disclosure in } \\
\text { financial } \\
\text { reports }\end{array}$ \\
\hline \multirow{3}{*}{$\begin{array}{l}\text { encouragement } \\
\text { of international } \\
\text { investments } \\
\text { (Foreign Direct } \\
\text { Investment) }\end{array}$} & $\begin{array}{l}\text { Pearson } \\
\text { Correlation }\end{array}$ & 1 & $0.891^{* *}$ \\
\hline & Sig. (2-tailed) & & .000 \\
\hline & $\begin{array}{l}\text { The number of } \\
\text { items of the } \\
\text { sample }\end{array}$ & 90 & 90 \\
\hline \multirow{3}{*}{$\begin{array}{l}\text { Disclosure } \\
\text { financial } \\
\text { reports } \\
\text { According } \\
\text { IFRS }\end{array}$} & $\begin{array}{l}\text { Pearson } \\
\text { Correlation }\end{array}$ & $0.891^{* *}$ & 1 \\
\hline & Sig. (2-tailed) & .000 & \\
\hline & $\begin{array}{l}\text { The number of } \\
\text { items of the } \\
\text { sample }\end{array}$ & 90 & 90 \\
\hline
\end{tabular}

**. Correlation is significant at the 0.01 level (2-tailed).

Table (6) The correlation effect of the disclosure of the financial reports "IFRS" on the encouragement of international investments (foreign direct investment) in the Kurdistan region-Iraq

\begin{tabular}{|c|c|c|c|c|c|}
\hline $\begin{array}{l}\text { In } \\
\text { depending } \\
\text { variable }\end{array}$ & $\mathrm{R}$ & $\mathrm{R} 2$ & $\begin{array}{c}\text { Adjusted } \\
\text { R2 }\end{array}$ & $\mathrm{F}$ & Sig. F \\
\hline $\begin{array}{l}\text { disclosure } \\
\text { of financial } \\
\text { reports } \\
\text { According } \\
\text { by IFRS }\end{array}$ & $0.724 a$ & 0.523 & 0.518 & 90.073 & 0.000 \\
\hline \multirow{2}{*}{\multicolumn{2}{|c|}{$\begin{array}{l}\text { encouragement of } \\
\text { international } \\
\text { investments (Foreign } \\
\text { Direct Investment) }\end{array}$}} & $(\beta)$ & $\mathrm{T}$ & Sig. T & Sig. \\
\hline & & $0.724 a$ & 9.491 & 0.000 & 0.01 \\
\hline
\end{tabular}

H6 There is a significant effect of the disclosure of financial reports by IFRS on the encouragement of international investments, including (foreign direct investments) in the

Kurdistan Region-Iraq. The results of Table (6) show that the correlation effect $(\mathrm{R}=0.724 \mathrm{a})$ indicates presence of a positive correlation effect of the variable of disclosure in financial reporting on the Foreign Direct Investment variable, and that there is an effect of the independent variable encouragement of international investments (foreign direct investment) on the dependent variable encouragement of international investments (foreign direct investment) which is a statistically significant effect, as the calculated value of $(\mathrm{F})$ reached (90.073) which is statistically significant at the level of $(\mathrm{Sig}=0.000)$ which is less than (0.05), and based on the above, the sixth hypothesis is accepted. Financial reports for companies and financial institutions through which the appropriate decision is taken, whether by management, investors, lenders, or any other party in need of financial reports. In the financial reports according to the International Financial Reporting Standards IFRS and the encouragement of international investments, including (foreign investments) direct prophetess in the Kurdistan Region-Iraq. Great for disclosure in the financial reports of companies, financial institutions, and banks through which the appropriate decision is taken, whether by the administration, investors, lenders, or any other party in need of financial reports, as they make a lot of efforts and funds by the decision- 
makers on the financial statements or the beneficiaries of the financial statements in order to obtain quality financial reports.

Table (7): The correlation coefficient between the relevance of financial reports by "IFRS", and the encouragement of international investments (foreign direct investment) in the Kurdistan Region

\begin{tabular}{|c|c|c|c|}
\hline & & $\begin{array}{c}\text { foreign } \\
\text { direct } \\
\text { investment }\end{array}$ & $\begin{array}{c}\text { International } \\
\text { Financial Reporting } \\
\text { Standards }\end{array}$ \\
\hline \multirow{3}{*}{$\begin{array}{l}\text { relevance of } \\
\text { financial } \\
\text { reports by } \\
\text { "IFRS }\end{array}$} & $\begin{array}{c}\text { Pearson } \\
\text { Correlation }\end{array}$ & 1 & $0.822^{* *}$ \\
\hline & Sig. (2-tailed) & & 0.000 \\
\hline & $\begin{array}{c}\text { The number } \\
\text { of items of the } \\
\text { sample }\end{array}$ & 90 & 90 \\
\hline \multirow{3}{*}{$\begin{array}{c}\text { encouragement } \\
\text { of international } \\
\text { investments } \\
\text { (foreign direct } \\
\text { investment) }\end{array}$} & $\begin{array}{c}\text { Pearson } \\
\text { Correlation }\end{array}$ & $0.822^{* *}$ & 1 \\
\hline & Sig. (2-tailed) & 0.000 & \\
\hline & $\begin{array}{c}\text { The number } \\
\text { of items of the } \\
\text { sample }\end{array}$ & 90 & 90 \\
\hline
\end{tabular}

${ }^{* *}$. Correlation is significant at the 0.01 level (2-tailed).

H7 There is a significant correlation between the relevance of financial reports by "IFRS", and the encouragement of international investments (foreign direct investment) in the Kurdistan Region. Based on the results of Table No. 7 the correlation coefficient was used to measure the relationship between the variable. The independent the relevance of financial reports by "IFRS" as it became clear from the analysis data that the correlation coefficient reached $0.822^{* *}$ at a significant level (0.000), which indicates that there is a direct correlation between the IFRS and the encouragement of international investments, including (foreign direct investments) in Kurdistan Region. Reducing the economic crisis that the Kurdistan Region is currently going through. Extracted from the financial reports, this is a study that showed the relationship of acceptable statistical significance because it is less than $1 \%$, which is the statistically acceptable level, and the strength of that relationship is strong. And based on the results of Table 7, the null hypothesis is rejected and the alternative hypothesis is converted (there is a correlation between IFRS and the encouragement of international investments, including (foreign direct investments) in the Kurdistan Region. As part of the solution to the economic crisis in Kurdistan, transparency, quality and disclosure are the features of international standards for financial reporting that have a positive and strong effect on encouraging foreign direct investment in the Kurdistan Region, and this result is consistent with the logic of economic theory; That is, the application of international financial reporting standards represented by transparency, quality and disclosure are available. There was greater encouragement for foreign direct investment in the region. This study demonstrated a positive relationship between the application of international accounting standards and the encouragement of foreign direct investment, meaning that when other factors remain constant, the application of international accounting standards in the Kurdistan Region contributes to encouraging foreign direct investment.

Table (8)The correlation effect of the relevance of the financial reports "IFRS" on the encouragement of foreign direct investment in the Kurdistan region-Iraq

\begin{tabular}{lccccc}
\hline $\begin{array}{l}\text { In depending } \\
\text { variable }\end{array}$ & $\mathrm{R}$ & $\mathrm{R} 2$ & $\begin{array}{c}\text { Adjusted } \\
\mathrm{R} 2\end{array}$ & $\mathrm{~F}$ & Sig. F \\
\hline $\begin{array}{l}\text { relevance of } \\
\text { financial } \\
\text { reports }\end{array}$ & $0.731 \mathrm{a}$ & 0.534 & 0.529 & 94.133 & 0.000 \\
$\begin{array}{l}\text { According by } \\
\text { IFRS }\end{array}$ & & & & & \\
\hline $\begin{array}{l}\text { encouragement of } \\
\text { international } \\
\text { investments (Foreign } \\
\text { Direct Investment) }\end{array}$ & $0.731 \mathrm{a}$ & 9.702 & 0.000 & 0.01 \\
\cline { 2 - 6 } & & & & & \\
\hline
\end{tabular}

H8 There is a significant effect of the relevance of financial reports by IFRS on the encouragement of international investments, including (foreign direct investments) in the Kurdistan Region-Iraq. The results of Table (8) show that the correlation effect of $(\mathrm{R}=0.731 \mathrm{a})$ indicates presence of a positive correlation effect of the variable of disclosure in financial reporting and the Foreign Direct Investment variable, and that there is an effect of the independent 
variable (relevance in financial reporting) on the dependent variable \{ Foreign Direct Investment which is a statistically significant effect, as the calculated value of $(\mathrm{F})$ reached (94.133) which is statistically significant at the level of $(\mathrm{Sig}=0.000)$ which is less than (0.05), and based on the above, the eighth hypothesis is accepted. Financial reports for companies and financial institutions through which the appropriate decision is taken, whether by management, investors, lenders, or any other party in need of financial reports. In the financial reports according to the International Financial Reporting Standards IFRS and the encouragement of international investments, including (foreign investments) direct prophetess in the Kurdistan Region-Iraq. As part of the solution to the economic crisis in Kurdistan, transparency, quality and disclosure are the features of international standards for financial reporting that have a positive and strong effect on encouraging foreign direct investment in the Kurdistan Region, and this result is consistent with the logic of economic theory; That is, the application of international financial reporting standards represented by transparency, quality and disclosure are available. There was greater encouragement for foreign direct investment in the region. This study demonstrated a positive role of the application of international accounting standards and the encouragement of foreign direct investment, meaning that when other factors remain constant, the application of international accounting standards in the Kurdistan Region contributes to encouraging foreign direct investment.

\section{Conclusions}

- The transparency, quality, disclosure and relevance present in IFRS have a significant role on encouragement of international investments, including (foreign investments), as the financial statements prepared under international accounting standards generate confidence in the foreign investor as shown by the results of the study.

- The International Financial Reporting Standards (IFRS) are considered a motive for reaching foreign investment because they help to generate unified financial reports that permit the elimination of international barriers between countries that have implemented full international financial reporting standards, and it also increases consistency between the financial reports of companies and banks that have been established in the region. It decreases the expenses of formulating and interpretation of financial statements and provides confidence in transactions and analysis of information.

- Despite the many difficulties and costs associated with applying the International Financial Reporting Standards IFRS, but there are many advantages related to the quality of financial reports that motivate their application, especially in the Kurdistan Region.

- Most developing countries, including the Kurdistan Region, will seek to attract foreign direct investment to it through improving the investment climate, which is considered an important thing that the foreign investor takes into consideration, in order to avoid risks that may role his activity, in addition to providing the necessary incentives and privileges that are provided by the financial statements prepared under international standards For financial reports, because foreign direct investment is of utmost importance in contributing to the achievement of development.

- There is a role ( correlation relationship \& effect) of IFRS and the encouragement of foreign direct investment to what the Kurdistan Region is exposed to in the current period of many financial 
and economic problems and difficulties, which appear in the deterioration of the financial and economic conditions of the region, which is reflected in the deterioration of the economy significantly, the results of this study proved On the need to apply international financial reporting standards as an important factor in attracting foreign capital for investment in a way that improves the economic life of the region and thus helps foreign direct investment in improving living and improving the financial and economic conditions of the Kurdistan Region.

\section{Recommendations}

- This study recommends the application of international standards for financial reporting in the Kurdistan region to enable local companies to merge orally with foreign companies and international dealings because lifting restrictions on the movement of investment, the expansion of the business of institutions at the international level and their association with international financial markets imposes a unified accounting language.

- The need for the Accountants and Auditors Association in the region to adopt training courses and seminars, the purpose of which is to train accountants and auditors on the requirements of the International Financial Reporting Standards (IFRS) because the commitment to apply international standards helps in attracting and attracting foreign investment.

- Focusing on demonstrating the economic benefits from applying international financial reporting standards, and the advantages that it achieves, whether companies or banks that use financial statements.

- Encouraging researchers to conduct recent studies to show the impact of foreign investment on financial crises, including unemployment, poverty, and the level of well-being in the Kurdistan Region to find out more advantages in applying international standards for financial reporting.

\section{References}

1. Abd al-Salam, Reda Muhammad (2002) Determinants of Foreign Direct Investment in the Age of Globalization, Mansoura, Egypt, Dar Al-Salam for Printing and Publishing, p. 7

2. Aida Lozada Rivera, Carmen Ríos Figueroa" IFRS FOR SME'S: Fashion Movement Or Route To Convergence" Revista Global De Negocios, Volumen 2 , Numero 1 ,www.ssrn.com, 2014.

3. Jaf, R. A. S., \& hamid Ahmad, K. A. (2021). The Role of Accounting Mechanisms for Bank Governance in Improving the Quality of the Information Content of the Interim Financial Reports: An Exploratory Study of The Opinions of a Sample of Workers In Private Iraqi Banks Operating In The Kurdistan Region/Iraq. QALAAI ZANIST SCIENTIFIC JOURNAL, 6(1), 279-305.

4. Al-Jarf, Yasser Ahmed, (2010), the importance of developing accounting standards in the Kingdom of Saudi Arabia to achieve compatibility with international accounting standards, a proposed framework. A working paper submitted to the Twelfth Symposium on Ways to Develop Accountancy in the Kingdom.

5. Al-Kafri, Mustafa Al-Abdullah (2010) Foreign direct investment in the Arab countries. Journal of the Syrian Economic Sciences Association.

6. Al-Kake, F., Harun, A., Othman, B., \& MH, N. (2019). The Effect of Corporate Governance on Firm's Profitability: Evidence from London Stock ExChange. International Journal of Psychosocial Rehabilitation, 23(2), 727-742.

7. Al-Majrabi, Fatima Ali Misbah, (2012) The Ability of Companies Listed in the Libyan Stock Market to Adopt and Apply International Financial Reporting Standards. Master Thesis, College of Business, Libyan Middle East University.

8. Al-Qashi, Zahir and Al-Abadi, Haitham (2007) The effect of adopting and applying international accounting standards in Jordanian companies on attracting foreign direct investment. Urge submitted to The Fifth Scientific Conference, entitled: Towards an Investment Climate and Electronic Banking Business, Philadelphia University - College of Administrative and Financial Sciences., Amman - Jordan

9. Al-Zomor, Imad Saeed (2012) "An Applied Study of the Impact of the Transition to International Financial Reporting Standards on the Quality of Financial Reports," The Scientific Journal of Economics and 
Trade, Faculty of Commerce, Ain Shams University, Issue Four, Volume Three, October.

10. Bradshaw, M., Bushee \& G.Miller, 2004, “Accounting Choice, Home Bias, and US Investment in Non-US Firms" Journal of Accounting Research Vol. 42 No. 5, December.

11. Jaf, R. A., Sabr, S. A., \& Nader, K. A. (2015). Impact of management accounting techniques on achieve competitive advantage. Research Journal of Finance and Accounting, 6(4), 84-99.

12. Jaf, R. A. S., Xinping, X., \& Jaf, S. A. S. (2012, January). The effect of the Strategic Information Systems (SIS) on the achievement competitive advantage practical in samples of iraqi banks. In 2012 Second International Conference on Intelligent System Design and Engineering Application (pp. 954-959). IEEE.

13. Hawass, Salah, (2008) The new trend towards financial reporting standards and its impact on the auditing profession, Ph.D. thesis, Faculty of Economic Sciences and Management Sciences, University of Algiers.

14. Holthausen, R., 2003, "Testing the Relative Power of Accounting Standards versus Incentives and other Institutional Features to Influence the Outcome of Financial

15. Kevin D.Steinbach and Roger Y.w.Tang .(2014)."IFRS Convergence:Learning Form Mexica,Brazial , and Argentina". The Journal of corporate Accounting \& Finance, March/March / April,31-40.

16. Kurtel, Farid and Bin Arab, Abdul Karim (2007) Forms and determinants of foreign direct investment with reference to its reality in Arab countries and some developing countries Research presented to: The Fifth Scientific Conference, entitled: Towards an Investment Climate and Electronic Banking Business, Philadelphia University - College of Science Administrative and Financial, Oman.

17. Metwally, Mr. Kayed, (2000) Towards an Intellectual Framework for International Accounting Consensus A Critical Analytical Study of the Role of the International Accounting Standards Committee", Journal of Financial and Business Studies, Faculty of Commerce - Beni Suef University - Cairo University, First Issue.

18. Othman, B. J., Al-Kake, F., Diah, M. L. M., Othman, B., Hussein, S., \& Hasan, N. M. (2019). Impact of the foreign direct investment on the economy of the United Kingdom. International Journal of Psychosocial Rehabilitation, 23(02).

19. Peter Jeffrey, 2002," International Harmonization of Accounting Standards and the Question of off-Balance Sheet Treatment", Duke Journal of Comparative \& International Law Vol. 12.

20. Pran Krishansing Boolaky, 2010" IFRS in Small IslandEconomies: Problems and challenges to the private andpublic-sector enterprises: Using data from mauritius"'"www.ssrn.com.

21. Ratnam Alagiah\& Tan Cheng LOK, (2013)"Establishing
aSystem of Accounting Standards: A Case Study of MacauWorld Review of Business Research,Vol. 3. No.

2. Issue. Pp. $14-24$

22. Reporting in an International Setting" Journal of Accounting and Economics.

23. Saskia K.S.Wilhelms (1998) : L'invetissement etrangér direct et ses elements déterminants dans les économies naissante,washington,Agence des etats unis pour le développement international, juillet 1998,pp :28-34. Voir Site Internet : www.eagerprojet.com.

24. Sorguli, S. H., \& Al-Kake, F. R. A. (2020). The impact of Accounting Information System on Internal Controls in Iraq. Solid State Technology, 63(5), 7024-7036.

25. The International Monetary Fund issued in March (2007). The draft of the sixth edition of the Balance of Payments Statistics Handbook, in which the international concept of foreign direct investment contained in conformity with that, replaces the fifth edition of the guide issued in 1993. Thus, the concepts and methodology of the new edition were applied to all countries of the world.

26. Sabir, R. A., Xinping, X., \& Sabr, S. A. (2011). Using target costing to investigates competitive price. World Academy of Science, Engineering and Technology, 5.

27. Watts R., 2003, "Conservatism in Accounting, Part I: Explanations and Implications." Accounting Horizons. 